Rev. Int. Contam. Ambie. 33 (1) 57-64, 2017

DOI: 10.20937/RICA.2017.33.01.05

\title{
LEAD EXPOSURE: POTTERY IMPACT IN TLAXCALA, MEXICO
}

\author{
Elvia ORTIZ-ORTIZ1 ${ }^{1}$, Edelmira GARCÍA-NIETO2*, Libertad JUÁREZ-SANTACRUZ ${ }^{2}$, \\ Madaí Angélica GÓMEZ-CAMARILLO ${ }^{3}$, Elizabeth GARCÍA-GALLEGOS ${ }^{2}$ y \\ Patricia LIMÓN-HUITRÓN ${ }^{1}$
}

${ }^{1}$ Facultad de Odontología, Universidad Autónoma de Tlaxcala. Avenida Ribereña sin número, Colonia Centro, Tlaxcala, México, C. P. 90000

${ }^{2}$ Centro de Investigación en Genética y Ambiente, Universidad Autónoma de Tlaxcala. Kilómetro10.5, Autopista San Martín-Tlaxcala, Ixtacuixtla, Tlaxcala, México, C. P. 90120

${ }^{3}$ Centro de Investigación en Reproducción Animal, Universidad Autónoma de Tlaxcala. Plaza Hidalgo sin número, Panotla, Tlaxcala, México, C. P. 90140

*Corresponding author: mirosgn@hotmail.com

(Received December 2015; accepted June 2016)

Key words: blood, food, pottery-glaze workers, children, LeadCare II System

\begin{abstract}
The objective of this work was to assess the blood lead level in paired samples of pottery-glaze workers to confirm the LeadCare ${ }^{\circledR}$ II System (LCS) reliability using this device in the general population, and quantify this metal in cooked food in lead-glazed containers. The blood lead measurement in pottery-glaze workers was carried out by graphite furnace atomic absorption spectrometry (GFAAS) and the LCS. this last method was also used in the general population. The food lead level was quantified through GFAAS. The paired data showed a significant correlation $(\mathrm{r}=0.976, \mathrm{p}<0.001)$, a mean difference of $3.3 \mu \mathrm{g} / \mathrm{dL}$ with limits of agreement between -2.4 to 9 and an intraclass correlation coefficient of 0.928 . These results indicate a good concordance between both methods. The blood lead median of $32.0 \mu \mathrm{g} / \mathrm{dL}$ and interquartile range (IQR) of 16.1 was higher in the pottery-glaze workers than in the general population (children $=5.4 \mu \mathrm{g} / \mathrm{dL}, \mathrm{IQR}=5.9$ and adults $=8.3 \mu \mathrm{g} / \mathrm{dL}, \mathrm{IQR}=2.7$ ). Lead in food exceeded the maximum level considered in the Codex alimentarius. Pottery persists as a potential risk in the Tlaxcala State population.
\end{abstract}

Palabras clave: sangre, alimentos, alfareros, niños, sistema LeadCare II

\section{RESUMEN}

El objetivo de este trabajo fue evaluar el nivel de plomo sanguíneo en muestras pareadas de alfareros para confirmar la confiabilidad del sistema LeadCare II (SLC) empleando este dispositivo en la población general, y cuantificar este metal en alimentos cocinados en recipientes de barro vidriado. La medición de plomo en sangre de los alfareros, se realizó por espectrometría de absorción atómica con horno de grafito (EAAHG) y el SLC, este último método fue utilizado también en la población general. El nivel de plomo en alimentos fue cuantificado por EAAHG. Los datos pareados mostraron una correlación significativa $(\mathrm{r}=0.976, \mathrm{p}<0.001)$, una diferencia media de $3.3 \mu \mathrm{g} / \mathrm{dL}$ 
con límites de concordancia de -2.4 a 9 y un coeficiente de correlación intraclase de 0.928; esos resultados indican concordancia entre los métodos. La mediana de plomo sanguíneo de $32.0 \mu \mathrm{g} / \mathrm{dL}$ y el rango intercuartílico (RIC) de 16.1 fue superior en los alfareros que en la población general (niños $=5.4 \mu \mathrm{g} / \mathrm{dL}, \mathrm{RIC}=5.9$ y adultos $=8.3$ $\mu \mathrm{g} / \mathrm{dL}, \mathrm{RIC}=2.7)$. La concentración de plomo en el alimento superó el nivel máximo que contempla el Codex alimentarius. La alfarería persiste como un riesgo potencial en la población Tlaxcalteca.

\section{INTRODUCTION}

The environmental exposures account for nearly 10 $\%$ of deaths and disease burden globally and around one quarter of deaths and disease burden in children less than 5 years of age. Among the five factors proposed by the World Health Organization (WHO) considered as environmental risk, the lead exposure accounts for about $0.6 \%$ of burden of disease in the world population (WHO 2009). Lead has originated environmental and human health problems around the world (Braun et al. 2014, Jeong et al. 2014, La llave et al. 2014, McElvenny et al. 2015). Various studies suggest that exposure to lead during childhood at levels under $10 \mu \mathrm{g} / \mathrm{dL}$ contributes to learning problems, hearing deficit, and a decline in the intellectual coefficient and cognitive capacities (Carta et al. 2013, Liu et al. 2014, Sánchez-Villegas et al. 2014, Taylor et al. 2014).

Efforts to decrease and control lead exposure are evident, although insufficient. A clear example would be its elimination as a detonation suppressant in gasoline, measure that has contributed to a reduction in the blood lead level (BLL) (Rothenberg et al. 1998, Flores and Albert 2004). On the other hand, the manufacture of glazed clay containers using lead-based enamels is regulated in Mexico by the NOM-231-SSA1-2002 (SSA 2002) and NOM-004SSA1-2013 (SSA 2013), besides for the past twenty years the use of free-lead enamels has been promoted, unfortunately there are potters who are not using them (Fonart and Blacksmith Institute 2010).

Pottery activity, as an environmental risk factor, has several fundamental points: 1) the occupational exposure related with the glazing process, in which lead-based enamels (greta, litharge and albayalde) are applied without wearing any protection; 2) the exposure of potters and general population who inhale smoke emitted by furnaces during the cooking of earthenware, and 3) the general population that utilizes glazed clay pots to cook, store and consume foods. In the state of Tlaxcala, México, there are thirteen towns dedicated to this activity (INEGI 2010), one of these is La Trinidad Tenexyecac, where BLL between 1.6 and $67.5 \mu \mathrm{g} / \mathrm{dL}$ have been reported in a population of 3 to 82 years old; and in soil, from 11.3 to $12150 \mathrm{mg} / \mathrm{kg}$ (Carrasco-Rivas 2006). After six years these concentrations remain high, in children $(6.2$ to $52.3 \mu \mathrm{g} / \mathrm{dL}$ ) and environment (411 to 2740 $\mathrm{mg} / \mathrm{kg}$ of soil) (Flores-Ramírez et al. 2012).

On the other hand, it is estimated that $30 \%$ of urban population is exposed to lead through the use of lead-glazed clay recipients, and the percentage increases among the rural population (Flores-Ramírez et al. 2012). In Tlaxcala, $80 \%$ of the population lives in urban zones, however a large percentage consume rice and beans cooked in such containers. Furthermore, a cultural trait of Tlaxcala inhabitants is to share with the entire community "el mole", a traditional Mexican sauce made with a blend of dried chili peppers, spices, nuts and seeds, cooked in enormous lead-glazed clay saucepans, during the religious festivities carried out in most of the towns.

The first interest of this work was to assess BLL in paired samples from potters in order to verify the precision and reliability of LeadCare II ${ }^{\circledR}$ System (LCS) in comparison with the results from the graphite furnace atomic absorption spectrometry (GFAAS). The LCS is certainly an appealing possibility when there is a lack of adequate analytical infrastructure to monitor low levels of lead on a large scale, and to evaluate the human health risk for chronic exposure to this metal. With this point in mind, the second goal of this work was to use the LCS in individuals without any occupational or environmental exposure history to pottery. Finally, the cultural characteristic of Tlaxcala State led us to the next objective, which was quantifying lead in three foods cooked in leadglazed clay recipients, since is an important and particular exposure route in general population.

\section{MATERIAL AND METHODS}

\section{Study population and blood sample collection}

As high-risk group a male population of potters ( 25 to 50 years old, $\mathrm{n}=25$ ) from the municipality 
of San Pablo del Monte, Tlaxcala was chosen. As low-risk group a population without occupational or environmental exposure to lead (general population) was taken in consideration. This population was composed of adult volunteers ( 22 to 36 years old, $n=9$ ) recruited in the Faculty of Agrobiology of the Universidad Autónoma de Tlaxcala, and children (3 to 14 years old, $\mathrm{n}=38$ ) who were receiving dental care in Faculty of Odontology from the same university. The criteria for inclusion were as follow: 1) a minimum time of residence of two years in Tlaxcala State; 2) working as potter at less two years in a continuous way for the high-risk group; 3) that the parents never had worked in the pottery production and do not live in pottery locations for the low-risk group. A questionnaire was used to know the residence place, the probable exposure sources and domestic habits, such as the use of lead-glazed clay containers.

To obtain the blood sample, a voluntary and informed consent was solicited, and signed by each participant, in the case of children by parents or legal guardian. A phlebotomy was performed using lead-free Vacutainer ${ }^{\circledR}$ tubes, with sodium heparin as anticoagulant (Ref 367878, Becton-Dickinson, Franklin Lakes, NJ, USA). The samples were analyzed immediately by LCS or stored at $4{ }^{\circ} \mathrm{C}$ until posterior analysis by GFAAS. The project protocol was conducted in accordance with the Declaration of Helsinki and was approved by the bioethics committee of the Faculty of Odontology from Autonomous University of Tlaxcala.

\section{Food sample collection}

In eighteen towns located at the center-south zone of Tlaxcala State were collected 18 rice samples, 13 beans samples, and 17 mole samples cooked in lead-glazed clay recipients. The dates considered to take the samples were the celebration of patron saint feasts (August 2009 to January 2010). As reference samples, in the municipality of Zacatelco, Tlaxcala, four samples of each food cooked in pewter recipients were taken. Approximately $50 \mathrm{~g}$ of each food were placed into plastic tubes and stored at $4{ }^{\circ} \mathrm{C}$ until posterior analysis. The $\mathrm{pH}$ was measured with a Denver Instrument $\mathrm{pH}$ Meter, Model 215.

\section{Graphite furnace atomic absorption spectrometry (GFAAS)}

The BLL in potters and food lead levels (FLL) were assessed by GFAAS (Perkin-Elmer, Model 3110), according the NOM-117-SSA1-1994 (SSA 1994) and NOM-EM-004-SSA1-1999 (SSA 1999), respectively. With regard to the blood, a matrix modifier $(0.5 \%$ ammonium diphosphate $-0.5 \%$ Triton
$\mathrm{X}-100$ in $0.2 \% \mathrm{HNO}_{3}$ ) was used according to Subramanian method (Subramanian 1989). In the case of food, an acid digestion ( $0.5 \mathrm{~g}$ of food, $10 \mathrm{~mL}$ of $67 \%$ $\mathrm{HNO}_{3}$, and 0.5 of perchloric acid) on hotplates at $80{ }^{\circ} \mathrm{C}$ was performed until the complete elimination of the organic matter. The digested solution was filtered through Whatman filter paper No. 1, and diluted to the mark in the flask of $25 \mathrm{~mL}$ with $0.2 \% \mathrm{HNO}_{3}$. As internal quality control a blood lead reference standard certified by the Centers for Disease Control and Prevention (CDC) of the United States was used, obtaining $98 \%$ accuracy.

\section{Anodic stripping voltammetry (LeadCare ${ }^{\circledR}$ II System)}

The electrochemical measurement of BLL in potters and the low-risk group was performed using the LCS, Model 70-6529 (ESA Magellan Biosciences, Chelmsford, MA, USA), validated by the CDC with an operating range from 3.3 to $65 \mu \mathrm{g} / \mathrm{dL}$. As a quality control, the system uses two lead concentrations (7.9 \pm 3.0 and $22.7 \pm 3.4 \mu \mathrm{g} / \mathrm{dL}$ ).

\section{Statistical analysis}

The BLL variables corresponding to the potters group analyzed by LCS and GFAAS behaved parametrically (Shapiro-Wilk $p=0.243$, homoscedasticity $p=0.290)$, therefore the results obtained with both methods were evaluated through the Pearson lineal correlation coefficient.

Bland-Altman plot is extensively used to quantify agreement between two quantitative measurements by constructing limits of agreement (LA). These statistical limits were calculated by using the mean difference \pm 1.96 standard deviation of the difference between two measurements (LCS vs GFAAS). The $95 \%$ confidence interval (CI) for the mean and for the LA were calculated. The concordance and the intraclass correlation coefficient (ICC), were obtained from an ANOVA to repeated measures, by using the following formula:

$I C C=\frac{k\left(S S_{\text {between }}-S S_{\text {total }}\right)}{(k-1) S S_{\text {total }}}$

where:

$k=$ number of observations taken from each individual (2)

$S S_{\text {between }}=$ sum of squares between individuals (6409.452)

$S S_{\text {total }}=$ total sum of squares (6648.037)

The BLL data obtained using the LCS, and the FLL data quantified by GFAAS presented a 
nonparametric distribution, consequently the statistical analysis was carried out using the median and the interquartile range (IQR) as dispersion measure. A one-way analysis of variance was also carried out through the Kruskall-Wallis's test followed by a Dunn's multiple comparison test (Post-Hoc) at statistical significance level of $p<0.05$ to compare the differences between the three groups of each variable: A) blood lead: children with BLL > $3.3 \mu \mathrm{g} / \mathrm{dL}$, low risk adult and potter adult, and B) food lead: rice, beans and mole. In addition, a Mann-Whitney's test at $\mathrm{p}<0.05$ was applied for comparing data pairs: 1) blood lead by gender, 2) blood lead by age, and 3) food lead by container type. The statistical package used was the SigmaPlot Version 11.0.

\section{RESULTS}

Figure 1 shows the significant correlation $(\mathrm{p}=$ 0.001 ) between the BLL in the potters analyzed by GFAAS and LCS in concentrations ranging from 20.9 to 53.3 and 13.7 to $52.1 \mu \mathrm{g} / \mathrm{dL}$, respectively.

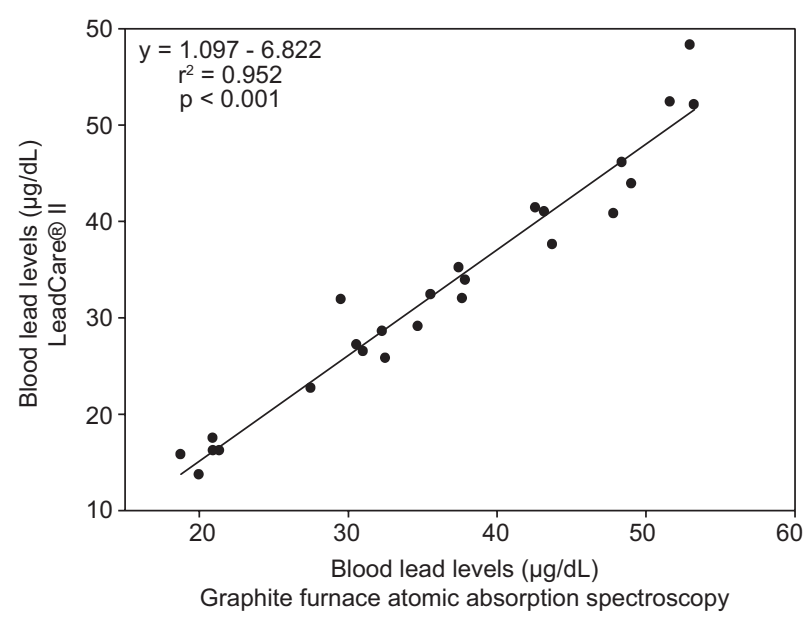

Fig. 1. Correlation between LeadCare $₫$ II System and graphite furnace atomic absorption spectroscopy for blood lead levels in potters. Pearson correlation coefficient $\mathrm{p}<0.001$, $\mathrm{n}=25$

The Bland-Altman plot illustrates the mean difference and the LA between both methods as well as the $95 \%$ CI. The mean difference (Fig. 2) indicates that BLL obtained through LCS method were $3.3 \mu \mathrm{g} / \mathrm{dL}$ lower than those measured by using GFAAS method, showing a CI between 2.1 to $4.5 \mu \mathrm{g} / \mathrm{dL}$ and a standard deviation of $2.9 \mu \mathrm{g} / \mathrm{dL}$.
The lower and upper limits of agreement between both methods ranged from $-2.4 \mu \mathrm{g} / \mathrm{dL}$ to $9.0 \mu \mathrm{g} /$ $\mathrm{dL}$, respectively.

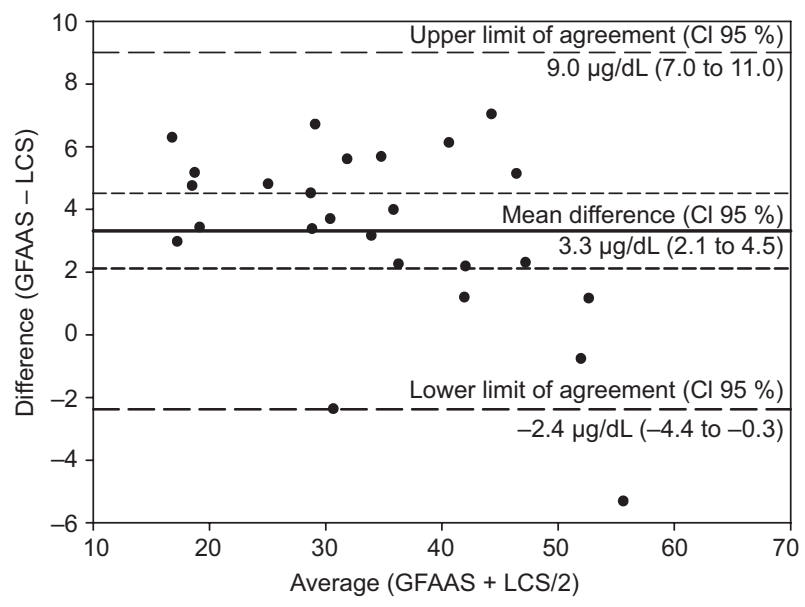

Fig. 2. Bland-Altman plot of differences between LCS and GFAAS method. LCS = LeadCare ${ }^{\circledR}$ II System, GFAAS = Graphite Furnace Atomic Absorption Spectroscopy. Solid line: mean difference between the measurements of blood lead obtained with the two methods. Short dotted lines: confidence interval $95 \%$ of the mean difference. Long dotted lines: upper and lower limits of agreement (mean difference \pm 1.96 standard deviation of the difference between two measurements)

The BLL median in the potters group $(32.2 \mu \mathrm{g} / \mathrm{dL}$, IQR $=16.1, n=26$ ) proved to be significantly higher $(p<0.05)$ than the values found in the children with BLL above detection limit of LCS $(5.4 \mu \mathrm{g} / \mathrm{dL}, \mathrm{IQR}=$ $5.9, \mathrm{n}=19)$ and adults $(8.3 \mu \mathrm{g} / \mathrm{dL}, \mathrm{IQR}=2.7, \mathrm{n}=9)$ from low-risk group, with no significant differences between these last groups (Fig. 3). When comparing the BLL in children by gender and age (Fig. 4), girls presented a median concentration $(4.9 \mu \mathrm{g} / \mathrm{dL}, \mathrm{IQR}=$ 4.1) apparently lower than the boys $(9.0 \mu \mathrm{g} / \mathrm{dL}$, IQR $=5.9$ ), however, there is no significant differences $(p=0.201)$. Similarly, the BLL in 3 to 8 years old children $(6.8 \mu \mathrm{g} / \mathrm{dL}, \mathrm{IQR}=6.5)$ was slightly higher than in 9 to 14 years old children $(5.4 \mu \mathrm{g} / \mathrm{dL}, \mathrm{IQR}$ $=5.2)$, with no significant differences $(\mathrm{p}=0.838)$.

As can be seen in figure 5, the food cooked in lead-glazed clay containers presented high concentrations of lead, with maximum values of 6.5,23.3 and $20 \mu \mathrm{g} / \mathrm{g}$ for rice, beans, and mole, respectively. A percentage of the samples equal to $87.5 \%$ exceed the 0.5 $\mu \mathrm{g} / \mathrm{g}$, value recommended by NOM-247-SSA1-2008 (SSA 2008) and $100 \%$ is above the international guidelines $(0.2 \mu \mathrm{g} / \mathrm{g})$ (WHO and FAO 2015).

The acid foods extract lead by lixiviation from lead-glazed clay containers. It should be mentioned 


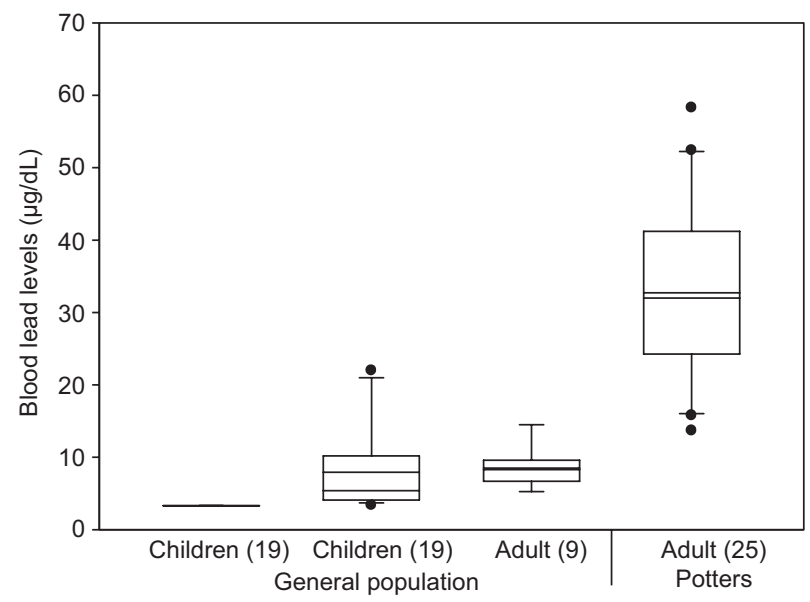

Fig. 3. Distribution of blood lead levels in general population and potters quantified by using LeadCare ${ }^{\circledR}$ II System. The first children group showed blood lead level lower than detection limit $(3.3 \mu \mathrm{g} / \mathrm{dL})$. Different letters indicate statistically significant difference. Kruskal-Wallis and Dunn's method $\mathrm{p}<0.05$

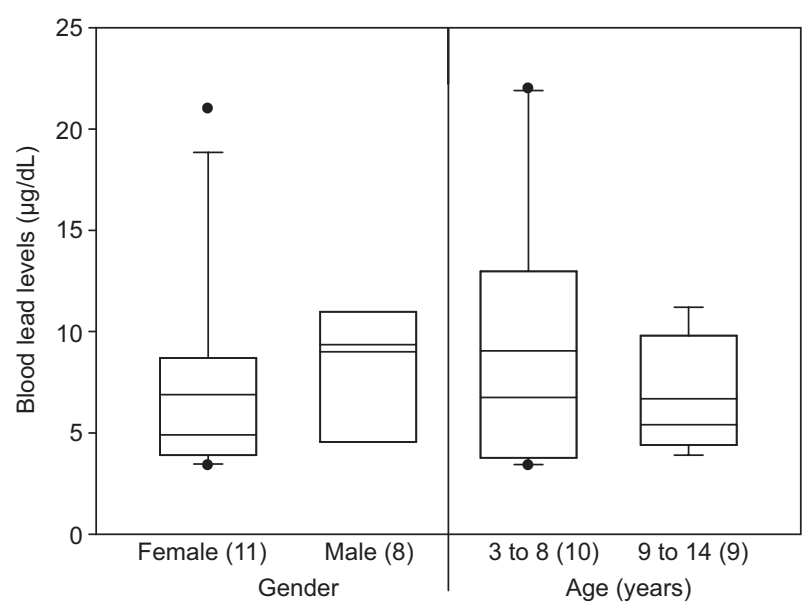

Fig. 4. Distribution of blood lead levels by gender and age in children from general population with values of blood lead upper than $3.3 \mu \mathrm{g} / \mathrm{dL}$ quantified by using LeadCare ${ }^{\circledR}$ II System. Mann-Whitney U* $\mathrm{p}<0.05$

that the three foods have an acid $\mathrm{pH}$ (rice $=4.88 \pm 0.30$, beans $=4.86 \pm 0.50$, and mole $=5.50 \pm 0.37$ ). The lead concentration in mole $(3.5 \mu \mathrm{g} / \mathrm{g}, \mathrm{IQR}=6.4)$ was statistically higher $(\mathrm{p}<0.05)$ than in rice $(1.1 \mu \mathrm{g} / \mathrm{g}$, $\mathrm{IQR}=2.9)$, but similar to beans $(1.7 \mu \mathrm{g} / \mathrm{g}, \mathrm{IQR}=5.8)$. The foods cooked in pewter containers showed lead concentrations significantly lower $(p<0.05)$ than those cooked in lead-glazed clay containers, since the values were $0.36 \mu \mathrm{g} / \mathrm{g}(\mathrm{IQR}=0.18)$ for rice, $0.32 \mu \mathrm{g} / \mathrm{g}$ $(\mathrm{IQR}=0.08)$ for beans, and $0.41 \mu \mathrm{g} / \mathrm{g}(\mathrm{IQR}=0.16)$ for mole. These FLL do not exceed the NOM-247SSA1-2008 (SSA 2008) but surpass the international guidelines (WHO and FAO 2015).

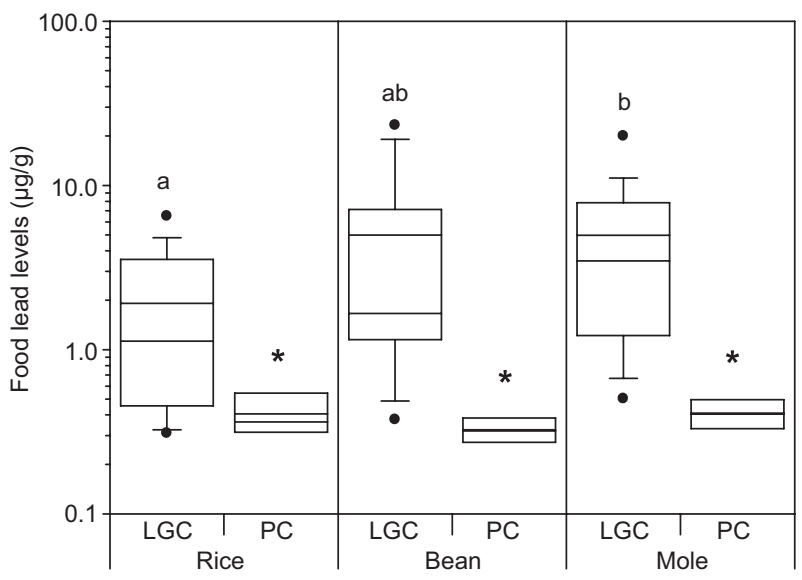

Fig. 5. Distribution of food lead levels cooked in LGC and PC quantified by using graphite furnace atomic absorption spectroscopy method. LGC = lead-glazed clay containers, $\mathrm{PC}=$ Pewter containers. Different letters indicate statistically significant difference between food cooking in LGC by Kruskal-Wallis and Dunn's method $\mathrm{p}<0.05$. Asterisk indicate statistically significant difference between food cooking in LGC and PC by Mann-Whitney $\mathrm{U}$ : rice $=0.045$, beans $\mathrm{p}=0.006$ and mole $\mathrm{p}=0.003$

\section{DISCUSSION}

The significant correlation $(\mathrm{r}=0.976, \mathrm{p}<0.001)$, the ICC (0.928), and the results from Bland-Altman plot in which $96 \%$ of the differences is within 1.96 of the standard deviation ( -2.4 to $9 \mu \mathrm{g} / \mathrm{g}$ ) from the mean difference $(3.3 \mu \mathrm{g} / \mathrm{dL})$, indicate a good accuracy and agreement between the methods. The results of this research are consistent with independent studies comparing LCS with GFAAS. In a study involving 208 paired samples, the mean difference was $3.41 \pm 7.61$ $\mu \mathrm{g} / \mathrm{dL}$ for $\leq 10 \mu \mathrm{g} / \mathrm{dL}$ values, and $0.57 \pm 5.35 \mu \mathrm{g} / \mathrm{dL}$ for $>10 \mu \mathrm{g} / \mathrm{dL}$ values, with a correlation coefficient of 0.819 in BLL in the range from 1 to $42 \mu \mathrm{g} / \mathrm{dL}$ (Taylor et al. 2001). Another study of 76 samples with a range of BLL from 1.5 to $53 \mu \mathrm{g} / \mathrm{dL}$ showed a correlation between both methods with an $r=0.95$ (Pineau et al. 2002).

For the mean of values obtained by LCS $(32.7 \pm$ $12.3 \mu \mathrm{g} / \mathrm{dL})$ and GFAAS $(36.0 \pm 10.9 \mu \mathrm{g} / \mathrm{dL})$ there was no significant difference $(\mathrm{p}=0.319)$. The BLL mean obtained by LCS was $9.2 \%$ lower than that obtained through GFAAS in the potters of San Pablo del Monte. This percentage was lower than the level reported in an infantile population $(\mathrm{n}=172)$ of El Paso, Texas, when comparing the LCS $(2.3 \pm 0.79 \mu \mathrm{g} / \mathrm{dL})$ with the inductively coupled plasma mass spectrometry method (2.8 $\pm 136 \mu \mathrm{g} / \mathrm{dL})$ (Sobin et al. 2011).

In order to carry out the clinical evaluation and the BLL monitoring, the use of this device is suggested. 
The BLL mean $(7.9 \pm 5.4 \mu \mathrm{g} / \mathrm{dL})$ determined in the children participating in this research by LCS was $38 \%$ higher than that found in Belizean children of $4.9 \pm$ $2.5 \mu \mathrm{g} / \mathrm{dL}$ (Charalambous et al. 2009). The BLL in the general population frequently is lower than that found in populations with environmental or occupational exposure to this compound. The BLL mean in the children analyzed in this study was $63 \%$ lower than children living in the vicinity of a lead smelter plant and artisanal battery recycling $(21.5 \pm 16.2 \mu \mathrm{g} / \mathrm{dL})$ in the village of Nghia, Vietnam (Sanders et al. 2014). On the other hand, higher concentrations are reported in children from Tlaxcala working in pottery $(19.4 \mu \mathrm{g} / \mathrm{dL})$, and from an area near a smelter in the state of Chihuahua, México, $(11.3 \mu \mathrm{g} / \mathrm{dL})$, but similar to those found in the children from the metallurgical area $(7.1 \mu \mathrm{g} / \mathrm{dL})$ in San Luis Potosí, México (FloresRamírez et al. 2012).

Environmental intervention, eating habits changes, or redistribution of blood lead to other tissues such as bones, are variables that have an influence on a BLL decrease regarding the age. Children aged 0 , 6,12 , and 60 months inhabiting in the surroundings of a smelter in Torreón, state of Coahuila, México, presented BLL median which decreased with age: $10.12 \mu \mathrm{g} / \mathrm{dL}$ (1.9 to 43.8$), 8.75 \mu \mathrm{g} / \mathrm{dL}$ (1.85 to 41.45$)$, $8.4 \mu \mathrm{g} / \mathrm{dL}$ (1.7 to 35.8 ), and $4.4 \mu \mathrm{g} / \mathrm{dL}$ (1.3 to 30.3 ), respectively (Rubio-Andrade et al. 2011). In this work a similar trend was observed, children aged 3 to 8 years had a BLL (median $6.8 \mu \mathrm{g} / \mathrm{dl}$, range 3.4 to 22) greater than children between 9 and 14 years old (median $5.4 \mu \mathrm{g} / \mathrm{dL}$, range 3.9 to 11.2 ), however there were no significant differences.

The exposure lead risk becomes evident when comparing the results with the NOM-199-SSA1-2000 (SSA 2000) and the protection guideline proposed by the CDC (2012). In this research paper $60 \%$ of the potters are classified in the category II ( 25 to $44 \mu \mathrm{g} / \mathrm{dL}$ ) and $16 \%$ are assigned to category III (45 to $69 \mu \mathrm{g} / \mathrm{dL}$ ), established in the Mexican regulation as key actions to protect human health (SSA 2000). The $86.8 \%$ infantile population falls into the category I given that has concentrations of less than $10 \mu \mathrm{g} / \mathrm{dL}$. Three children were encountered in the category II (10 to $14 \mu \mathrm{g} / \mathrm{dL}$ ), and two in the category III, since had concentrations ranging from 21 to $22 \mu \mathrm{g} / \mathrm{dL}$.

The $7 \%$ of children analyzed in a Belizean general population, have been reported values of BLL ranging from 10 to $14 \mu \mathrm{g} / \mathrm{dL}$. In a population exposed to emissions from a lead smelter and artisanal battery recycling plant it was found that $80 \%$ of children have concentrations higher than $10 \mu \mathrm{g} / \mathrm{dL}$
(Charalambous et al. 2009), in the same industrial sector, but in the city of Avalos, Chihuahua, this percentage was $34 \%$ (Flores-Ramírez et al. 2012). Twenty and twelve percent of children living near a metallurgical (copper smelting and electrolytic zinc smelting) and mining-metallurgical area, as well as $15 \%$ of potter children in the Trinidad Tenexyecac, Tlaxcala, were assigned to the category II of the Mexican regulation (Flores-Ramírez et al. 2012).

In accordance with the CDC (2012) the effects on the neurological system in children start at concentrations of $5 \mu \mathrm{g} / \mathrm{dL}$. It is important to underline that $29 \%$ of the children in this study exceeded this value. The LCS has been shown to be a useful method to assess neurobehavioral disorders. One study carried out in India with children found an association between the BLL $(11.4 \pm 5.3 \mu \mathrm{g} / \mathrm{dL})$ and social problems $(\beta=0.20, p=0.02)$, anxiety $(\beta=0.27, p=0.01)$, attention-deficit and hyperactivity disorder $(\beta=0.17$, $p=0.05$ ) (Roy et al. 2009). In the same population, the increase of $14 \mu \mathrm{g} / \mathrm{dL}$ was associated with a decrease of 2.6 points in the visuomotor skills, and 2.9 in the component drawing of these (Palaniappan et al. 2011). Nevertheless, it is suggested to be cautious about using the LCS to assess thresholds of neurotoxic effects lower than $10 \mu \mathrm{g} / \mathrm{dL}$ (Sobin et al. 2011).

\section{CONCLUSIONS}

From a socioeconomic point of view, using leadglazed clay containers is a cultural trait of the inhabitants of Tlaxcala State, and the pottery is an important source of work. The results suggest that there is a potential risk to general population of this State, given that $100 \%$ of the interviewees employ lead-glazed clay earthenware to cook, store or consume foods. The 48 samples of food cooked in such recipients had high concentrations of lead. It is therefore important that the inspection programs verify the changeover to enamel without lead and that compliance with the Mexican regulations are permanent and ongoing, as well as reinforcing the public health program of the State to reduce the exposure to this metal and to protect the population.

\section{REFERENCES}

Braun J. M., Wright R. J., Just A. C., Power M. C., Tamayo Y Ortiz M., Schnaas L., Hu H., Wright R. O. and Tellez-Rojo M. M. (2014). Relationships between lead biomarkers and diurnal salivary cortisol indices in 
pregnant women from Mexico City: a cross-sectional study. Environ. Health. 13, 50.

DOI: $10.1186 / 1476-069 \mathrm{X}-13-50$

Carrasco-Rivas G. (2006). La Trinidad Tenexyecac. Transformación histórica-económica y el impacto en la salud de una comunidad agrícola-cerámica de Tlaxcala. Universidad Autónoma de Tlaxcala. Tlaxcala, Mexico, 318 pp.

Carta P., Aru G., Carta L., Carta R. and Ibba A. (2013). Intelligence and neurocognitive tests among students living in a industrialized region of Sardinia with relatively low blood levels of lead. G. Ital. Med. Lav. Ergon. 35, 32-35.

CDC (2012). Low level lead exposure harms children: A renewed call for primary prevention. Report of the advisory committee on childhood lead poisoning prevention. Report. Centers for Disease Control and Prevention. Atlanta, GA, USA, 65 pp.

Charalambous A., Demoliou K., Mendez M., Coye R., Solorzano G. and Papanastasiou E. (2009). Screening for lead exposure in children in Belize. Rev. Panam. Salud Pública 25, 47-50.

DOI: $10.1590 /$ S1020-49892009000100007

Flores J. and Albert L.A. (2004). Environmental lead in Mexico, 1990-2002. En: Reviews of environmental contamination and toxicology, Vol. 181 (G. W. Ware, Ed.). Springer-Verlag, New York, USA, pp. 37-109.

Flores-Ramírez R., Rico-Escobar E., Núñez-Monreal J. E., García-Nieto E., Carrizalez L., Ilizaliturri-Hernández C. and Díaz-Barriga F. (2012). Exposición infantil al plomo en sitios contaminados. Salud Pública México 54, 383-392.

Fonart and Blacksmith Institute (2010). Uso de plomo en la alfarería en México. Report. Fondo Nacional para el Fomento de las Artesanías. Mexico City, Mexico, 51 pp.

INEGI (2010). Instituto Nacional de Estadística y Geografía. Artesanos adscritos al fideicomiso casa de las artesanías por municipio según principales tipos de artesanías [online]. http:www.inegi.org.mx/est/contenidos/espanol/sistemas/aee12/info/tlax/c29_10.xls 20/01/2016.

Jeong S. W., Lee C. K., Suh C. H., Kim K. H., Son B. C., Kim J. H., Lee J. T., Lee S. W. Park Y. B., Lee J. W., Yu S. D., Moon C. S., Kim D. H. and Lee S. Y. (2014). Blood lead concentration and related factors in Korea from the 2008 national survey for environmental pollutants in the human body. Int. J. Hyg. Environ. Health. 217, 871-877. DOI: 10.1016/j.ijheh.2014.06.006

La Llave L. O., Salas P. J. M., Estrada M. S., Sandoval C. A., Lechuga Q. A. M., Esquivel R. E. and García V. G. (2014). Impact of occupation on blood lead levels in pregnant women. Occup. Environ. Med. 71, A92. DOI: 10.1136/oemed-2014-102362.286
Liu J., Liu X., Wang W., McCauley L., Pinto-Martin J., Wang Y., Li L., Yan C. and Rogan W. J. (2014). Blood lead concentrations and children's behavioral and emotional problems: a cohort study. JAMA Pediatr. 168, 737-745. DOI: 10.1001/jamapediatrics. 2014.332

McElvenny D. M., Miller B. G., MacCalman L. A., Sleeuwenhoek A., van Tongeren M., Shepherd K., Darnton A. J. and Cherrie J. W. (2015). Mortality of a cohort of workers in Great Britain with blood lead measurements. Occup. Environ. Med. 72, 625-632. DOI: 10.1136/oemed-2014-102637

Palaniappan K., Roy A., Balakrishnan K., Gopalakrishnan L., Mukherjee B., Hu H. and Bellinger D. C. (2011). Lead exposure and visual-motor abilities in children from Chennai, India. Neurotoxicology 32, 465-470. DOI: 10.1016/j.neuro.2011.03.011

Pineau A., Fauconneau B., Rafael M., Viallefont A. and Guillard O. (2002). Determination of lead in whole blood: comparison of the leadcare blood lead testing system with Zeeman longitudinal electrothermal atomic absorption spectrometry. J. Trace. Elem. Med. Biol. 16, 113-117. DOI: 10.1016/S0946-672X(02)80037-2

Rothenberg S. J., Schnaas L., Perroni E., Hernández R. M. and Karchmer S. (1998). Secular trend in blood lead levels in a cohort of Mexico City children. Arch. Environ. Health. 53, 231-235.

DOI: $10.1080 / 00039899809605700$

Roy A., Bellinger D., Hu H., Schwartz J., Ettinger A. S., Wright R. O., Bouchard M., Palaniappan K. and Balakrishnan K. (2009). Lead Exposure and behavior among young children in Chennai, India. Environ. Health Perspect. 117, 1607-1611.

DOI: $10.1289 /$ ehp. 0900625

Rubio-Andrade M., Valdés-Pérezgasga F., Alonso J., Rosado J. L., Cebrián M. E. and García-Vargas G. G. (2011). Follow-up study on lead exposure in children living in a smelter community in northern Mexico. Environ. Health 10, 66. DOI: 10.1186/1476-069X-10-66

Sánchez-Villegas M. del C., Cortés-Vargas A., HidalgoLuna R. G., Alam-Escamilla D. A., Vargas-García V. M. and Loría-Castellanos J. (2014). Niveles de plomo en niños con diagnóstico de trastorno con déficit de atención e hiperactividad. Rev. Med. Inst. Mex. Seguro Soc. 52, 20-27.

Sanders A. P., Miller S. K., Nguyen V., Kotch J. B. and Fry R. C. (2014). Toxic metal levels in children residing in a smelting craft village in Vietnam: a pilot biomonitoring study. BMC Public Health 14, 114.

DOI: $10.1186 / 1471-2458-14-114$

Sobin C., Parisi N., Schaub T. and de la Riva E. (2011). A Bland-Altman comparison of the LeadCare ${ }^{\circledR}$ System and inductively coupled plasma mass spectrometry for 
detecting low-level lead in child whole blood samples. J. Med. Toxicol. 7, 24-32.

DOI: $10.1007 / \mathrm{s} 13181-010-0113-7$

SSA (1994) Norma Oficial Mexicana NOM-117SSA1-1994. Método de prueba para la determinación de cadmio, arsénico, plomo, estaño, cobre, fierro, zinc $\mathrm{y}$ mercurio en alimentos, agua potable y agua purificada por espectrofotometría de absorción atómica. Secretaría de Salud. Diario Oficial de la Federación. 5 de agosto de 1994.

SSA (1999) Norma Oficial Mexicana de Emergencia, Salud Ambiental NOM-EM-004-SSA1-1999. Criterios para la determinación de los niveles de concentraciones de plomo en la sangre. Acciones para proteger la salud de la población no expuesta ocupacionalmente. Métodos de prueba. Diario Oficial de la Federación. 25 de junio de 1999.

SSA (2000) Norma Oficial Mexicana NOM-199SSA1-2000. Salud ambiental. Niveles de plomo en sangre y acciones como criterios para proteger la salud de la población expuesta no ocupacionalmente. Diario Oficial de la Federación. 18 de octubre de 2002.

SSA (2002) Norma Oficial Mexicana NOM-231SSA1-2002. Artículos de alfarería vidriada, cerámica vidriada y porcelana. Límites de plomo y cadmio solubles, Métodos de ensayo. Diario Oficial de la Federación. 01 de agosto de 2003.

SSA (2008) Norma Oficial Mexicana NOM-247SSA1-2008. Productos y servicios. Cereales, harinas de cereales, sémolas o semolinas. Alimentos a base de: cereales, semillas comestibles, de harinas, sémolas o semolinas o sus mezclas. Productos de panificación. Disposiciones y especificaciones sanitarias y nutrimentales. Métodos de prueba. Diario Oficial de la Federación. 27 de julio de 2009.

SSA (2013) Norma Oficial Mexicana NOM-004SSA1-2013. Salud ambiental. Limitaciones y especificaciones sanitarias para el uso de los compuestos de plomo. Diario Oficial de la Federación. 02 de mayo de 2014.

Subramanian K. S. (1989). Determination of lead in blood by graphite furnace atomic absorption spectrometry-a critique. Sci. Total Environ. 89, 237-250.

DOI: 10.1016/0048-9697(89)90263-5

Taylor L., Jones R. L., Kwan L., Deddens J. A., Ashley K. and Sanderson W. T. (2001). Evaluation of a portable blood lead analyzer with occupationally exposed populations. Am. J. Ind. Med. 40, 354-362.

DOI: 10.1002/ajim.1109

Taylor M. P., Winder C. and Lanphear B. P. (2014). Australia's leading public health body delays action on the revision of the public health goal for blood lead exposures. Environ. Int. 70, 113-117. DOI: $10.1016 /$ j.envint.2014.04.023

WHO (2009). Global health risks: Mortality and burden of disease attributable to selected major risks. World Health Organization. Geneva, Switzerland, 70 pp.

WHO and FAO (2015). Codex alimentarius international food standards. General Standard for Contaminants and Toxins in Food and Feed (CODEX STAN 193-1995). World Health Organization and Food Agriculture Organization of the United Nations, USA, 59 pp. 